\title{
The Effect of Coffee Arabica Gayo Leaf Extract (Coffea arabica L.) on Increased PI3K Serum Levels in Type 2 Diabetic Rat
}

Sake Juli Martina ${ }^{1,2 *}$, Aznan Lelo ${ }^{1}$, Dharma Lindarto ${ }^{3}$, Ratna Akbari Ganie ${ }^{4}$, Muhammad Ichwan ${ }^{1}$, Hanifah Yusuf ${ }^{5}$, Syafruddin llyas ${ }^{6}$, Iqbal Pahlevi Nasution ${ }^{7}$

${ }^{1}$ Department of Pharmacology and Therapeutics, Faculty of Medicine, Universitas Sumatera Utara, Medan, Indonesia; ${ }^{2}$ Universitas Sumatera Utara Hospital, Medan, Indonesia; ${ }^{3}$ Department of Internal Medicine, Faculty of Medicine, Universitas Sumatera Utara, Medan, Indonesia; ${ }^{4}$ Department of Clinical Pathology, Faculty of Medicine, Universitas Sumatera Utara, Medan, Indonesia; ${ }^{5}$ Department of Pharmacology, Faculty of Medicine, Universitas Syiah Kuala, Banda Aceh, Indonesia; ${ }^{6}$ Department of Biology, Faculty of Mathematics and Natural Sciences, Universitas Sumatera Utara, Medan, Indonesia; ${ }^{7}$ Department of Pediatric Surgery, Faculty of Medicine, Universitas Sumatera Utara, Medan, Indonesia

Edited by: Sinisa Stojanosk Citation: Martina SJ, Lelo A, Lindarto D, Ganie RA, Ichwan M, Yusuf H, llyas S, Nasution IP. The Effect of Coffee Arabica Gayo Leaf Extract (Coffea arabica L.) on Increased PI3K Serum Levels in Type 2 Diabetic Rat.
Aned Sci. 2021 Jun 23; 9(T3):294-297.

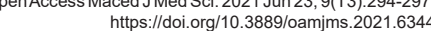
Keywords: PI3K; Coffee arabica gayo leaf extract; Type *Correspondence: Sake Juli Martina, Department of Pharmacology and Therapeutics, Faculty of Medicine niversitas Sumatera Utara, JI Dr. Mansur No. 5 Kampus USU Medan, Indonesia. E-mail: sake@usu.ac.id Received: 28-Apr-202 Revised: 28-May-2021 Copyright: ๑ 2021Sake Juli Martina, Aznan Lelo, Dharma Lindarto, Ratna Akbari Ganie Dharma Lindarto, Ratna Akbari Ganie,
Muhammad Ichwan, Hanifah Yusuf, Syafruddin llyas, Iqbal Pahlevi Nasutio Funding: This study was supported by Universitas Utara, the Ministry of Research and Technology, and the Higher Education Republic of Indonesia
Competing Interests: The authors have declared that no Open Access: This is an open-access article distributed under the terms of the Creative Commons AtributionNonCommercial 4.0 International License (CC BY-NC 4.0)

\begin{abstract}
BACKGROUND: Coffee arabica gayo leaf extract (Coffea arabica L.) contains polyphenols (chlorogenic acid), flavonoids, saponins, tannins, and steroids which improved PI3K serum levels in rats type 2 diabetic rat.

AIM: The purpose of the study was to determine the effect of Coffee Arabica Gayo Leaf Extract (C. arabica L.) on increased PI3K serum levels in type-2 diabetic rat (Rattus norvegicus).

METHODS: Thirty-five male Wistar rats with type 2 diabetic induced a combination of feeding a high-fat diet for 5 weeks and intraperitoneal injection of low dose streptozotocin $(30 \mathrm{mg} / \mathrm{kg})$. The diabetic rats were randomly divided into seven groups which consist of group without type 2 diabetic, group without type 2 diabetic with dose $250 \mathrm{mg} / \mathrm{kg} /$ day Coffee Arabica Gayo Leaf Extract, group with type 2 diabetic without intervention, group with type 2 diabetic with metformin, and group with type 2 diabetic with Coffee Arabica Gayo Leaf Extract doses 150, 200 , and $250 \mathrm{mg} / \mathrm{kg} /$ day. The extract was administered orally for 30 days. Subsequently, PI3K serum levels were
\end{abstract} measure by Sandwich Elisa.

RESULTS: There were significantly higher PI3K serum levels in the treatment groups than in the control groups $(p=0.037$ ) after giving Coffee Arabica Gayo Leaf Extract $200 \mathrm{mg} / \mathrm{kg} / \mathrm{day}$ and $250 \mathrm{mg} / \mathrm{kg} / \mathrm{day}$ to rats for 30 days.

CONCLUSION: These data suggest that Coffee Arabica Gayo Leaf Extract can improve PI3K serum levels in a rat model type 2 diabetic.

\section{Introduction}

According to the International Diabetes Federation in 2019, currently, more than 463 million people in the world live with diabetes mellitus (DM) and about $90 \%$ of DM cases in the world are type 2 DM (T2DM). Various epidemiological studies have shown a tendency to increase the incidence and prevalence of T2DM in various parts of the world. From these data, it is predicted that the prevalence of DM throughout the world will increase to 578 million in 2045 [1]. The World Health Organization predicts that the increase in the number of DM in Indonesia will increase 2-3 times from 8.4 million in 2000 to around 21.3 million in 2030 [2]. At present, Indonesia is ranked $7^{\text {th }}$ in the world for the highest number of DM sufferers in adults with an age range of 20-79 years with a total of 11.7 million people.
The increasing number of diabetics and the weak progress of disease cure encourage the world of health to further develop treatment in treating diabetes so that it does not cause microvascular and macrovascular complications and shows a good prognosis. However, the economic problem that often becomes a problem in DM treatment causes a low number of patients who get a good prognosis, so that alternative medicine is sought after by the public. Of the various alternative treatments that have emerged in the community, coffee leaves are one of the alternative treatments for which its efficacy is still little researched. Utilization of the coffee plant is currently still focused on seeds, while coffee leaves have not been widely used either as food products or as natural mixtures for food fortification, let alone medicine. Research by Martina (2019) shows that there is no significant difference between the benefits of coffee bean extract and coffee leaf extract in healthy 
rats on reducing blood sugar levels. Both provide the same effect of lowering blood sugar levels compared to placebo [3]. In Sumatra, especially coffee leaves are served as a brewed drink called "Aia Kawa" which is believed to contain polyphenol, flavonoids, and caffeine that can prevent various diseases, one of which is carcinogenic disease [4].

Chlorogenic acid (CGA) is able to inhibit hepatic glucose production by inhibiting hepatic glucose-6phosphatase translocase from the hepatic glucose-6phosphatase system [5]. Data on the composition of CGA in beverages and other food ingredients are rarely found in the literature except for coffee, which is one of the best sources of CGA [6]. Types of coffee leaves, especially arabica, show a high accumulation of CGA in young leaves [7].

Where CGA is found, it can stimulate glucose uptake through the activity of PI3K (Phosphatidylinositol 3-Kinase) in the body. PI3K activity in the body causes a decrease in glucose production in the liver and fat synthesis so that CGA functions as a good antidiabetic for DMT2 [8], [9]. Therefore, this study was conducted to determine the effect of Coffee Arabica Gayo Leaf Extract on changes in blood sugar levels in T2DM rats.

\section{Research Methodology}

\section{Research Type and Location}

This research was conducted with true experimental study with a post-test control group design. The research was conducted at the Pharmacology and Therapeutic Laboratory of the Faculty of Medicine, Universitas Sumatera Utara. Examination of PI3K serum levels was carried out at the Integrated Laboratory of the Faculty of Medicine, Universitas Sumatera Utara.

\section{Material}

In this study, the material was:

1. Metformin

2. Ethanol extract from Coffee Arabica Gayo Leaf (C. arabica L.).

\section{Animal}

This study used male white rats, Wistar strain aged 8 weeks with a body weight of 180-200 g, and the mice used were healthy and had never been tried in other studies. Using Federer's formula (1963), all experimental animals used were around 35 rats [10].

\section{Induction DM}

Rats were acclimatized for 7 days, given food and drink ad libitum. One mouse was placed in a cage in a room with a temperature of $22-25^{\circ} \mathrm{C}$ with a light-dark cycle of $12 / 12 \mathrm{~h}$. The mice were given a standard diet consisting of $12 \%$ fat, $60 \%$ carbohydrates, and $28 \%$ protein for 2 days, then were given a high-fat diet (HFD) consisting of $41 \%$ fat, $41 \%$ carbohydrates, and $18 \%$ protein for 5 weeks. After 5 weeks, the rats were fasted for 1 night, then they were injected with a low dose of streptozotocin $(30 \mathrm{mg} / \mathrm{kg}$ in 0.1 citrate buffer, $\mathrm{pH} 4.5)$ = intraperitoneally. Injection of streptozotocin dose of $30 \mathrm{mg} / \mathrm{kg}$ in 0.1 citrate buffer, $\mathrm{pH} 4.5$ was repeated for the following week. After 1 week of the second administration of streptozotocin, blood sugar levels when checked with a glucometer and if more than $200 \mathrm{mg} / \mathrm{dl}$ then fasting blood sugar levels and fasting insulin levels are checked to ensure insulin resistance and T2DM have occurred in experimental animals. When measuring blood sugar levels above $200 \mathrm{mg} / \mathrm{dl}$, rats are said to have T2DM.

\section{Treatment}

Wistar rats that had been induced with HFD/ streptozotocin (STZ) were then found to have blood sugar levels indicating a value that indicated T2DM on the measurement of blood sugar. Wistar rats were divided into 2 large groups, namely the normal group that was not made the T2DM model $(n=10)$ and the T2DM model group $(n=25)$. All experimental animals in the T2DM model group were induced with a low dose of STZ $30 \mathrm{mg} / \mathrm{kg}$ (1-week interval) after being given a HFD for 5 weeks to make it a T2DM model. Wistar rats that had become T2DM were divided randomly into 5 groups, namely the T2DM group without treatment $(n=5)$, the T2DM group with metformin ( $n=5)$, the T2DM group with the administration of Coffee Arabica Gayo Leaf extract at a dose of $150 \mathrm{mg} / \mathrm{kg} /$ day $(\mathrm{n}=5)$, the DMT2 group was given the Coffee Arabica Gayo Leaf extract at a dose of $200 \mathrm{mg} / \mathrm{kg} /$ day $(\mathrm{n}=5)$, and the T2DM group was given the Coffee Arabica Gayo Leaf extract at a dose of $250 \mathrm{mg} / \mathrm{kg} /$ day $(\mathrm{n}=5)$. Likewise, the group of mice that were not made the T2DM model was divided into 2 groups randomly, namely the normal control group without treatment $(n=5)$ and the normal control group with the administration of Coffee Arabica Gayo Leaf extract at a dose of $250 \mathrm{mg} / \mathrm{kg} /$ day $(n=5)$. Hence, the total number of groups $(t)$ in this study was 7 groups, which consist of 2 Normal groups and 5 T2DM groups. Of these 7 groups, there were 2 groups that did not receive treatment ( $\mathrm{K} 1$ and $\mathrm{K} 3$ ) and 5 groups that received treatment (K2, K4, $\mathrm{K} 5, \mathrm{~K} 6, \mathrm{~K} 7$ ). The extract was administered at a dose of $150 \mathrm{mg} / \mathrm{kg} / \mathrm{day}, 200 \mathrm{mg} / \mathrm{kg} /$ day, and $250 \mathrm{mg} / \mathrm{kg} /$ day through a nasogastric tube orally for 30 days. 


\section{Blood sugar check procedure}

The measured rat blood was taken from a lateral vein in the rat's tail. The tip of the tail was sheared, then pressed until the blood dropped and finally placed into the glucometer.

\section{Statistical analysis}

The sample in this study was normally distributed, so Shapiro-Wilk test is carried out. Data were presented in the form of mean standard deviation. To show the differences between groups (control and treatment), we used one-way ANOVA test analysis with SPSS computer program and a significance limit of $p<0.05$.

\section{Results and Discussion}

Based on the research, from 35 mice analyzed, there were significant changes in PI3K serum levels before and after the intervention of each group. The results are as follows in Table 1.

Table 1 shows the mean PI3K serum levels in the control group were lower than the treatment group. The order of the mean PI3K serum levels of male Wistar rats after giving Coffee Arabica Gayo Leaf Extract from the largest to the smallest was K4 $(7.54 \pm 0.08 \mathrm{ng} / \mathrm{dl})>$ $\mathrm{K} 7(7.35 \pm 0.24 \mathrm{ng} / \mathrm{dl})>\mathrm{K} 6(7.18 \pm 0.18 \mathrm{ng} / \mathrm{dl})>\mathrm{K} 2$ $(7.09 \pm 0.36 \mathrm{ng} / \mathrm{dl})>\mathrm{K} 1(7.08 \pm 0.12 \mathrm{ng} / \mathrm{dl})>\mathrm{K} 3(6.75$ $\pm 0.30 \mathrm{ng} / \mathrm{dl})>\mathrm{K} 5(6.22 \pm 0.08 \mathrm{ng} / \mathrm{dl})$. It can be seen that there is a decrease in PI3K serum levels by giving Coffee Arabica Gayo Leaf Extract to male Wistar rats with DMT2 model and it is statistically significant. From Table 1, it can be seen that the ethanol extract group of Coffee Arabica Gayo Leaf at a dose of $250 \mathrm{mg} / \mathrm{kg} /$ day (K7) and a dose of $200 \mathrm{mg} / \mathrm{kg} /$ day (K6) had a mean $\mathrm{PI3K}$ serum level higher than the normal group (K1). However, the highest levels were in the group that received metformin (K4).

Figure 1 shows that the mean PI3K serum levels of male Wistar rats after intervention were higher than PI3K serum levels except in the untreated T2DM group (K3). The highest PI3K serum levels were in the T2DM group that received metformin (K4), while the highest PI3K score was found in the DMT2 group who received ethanol extract of Gayo Arabica Coffee Leaves at a dose of $250 \mathrm{mg} / \mathrm{kg} /$ day. In addition, we can also see that the ethanol extract dose of $200 \mathrm{mg} / \mathrm{kg}$ (K6) has not been able to match the results of the PI3K

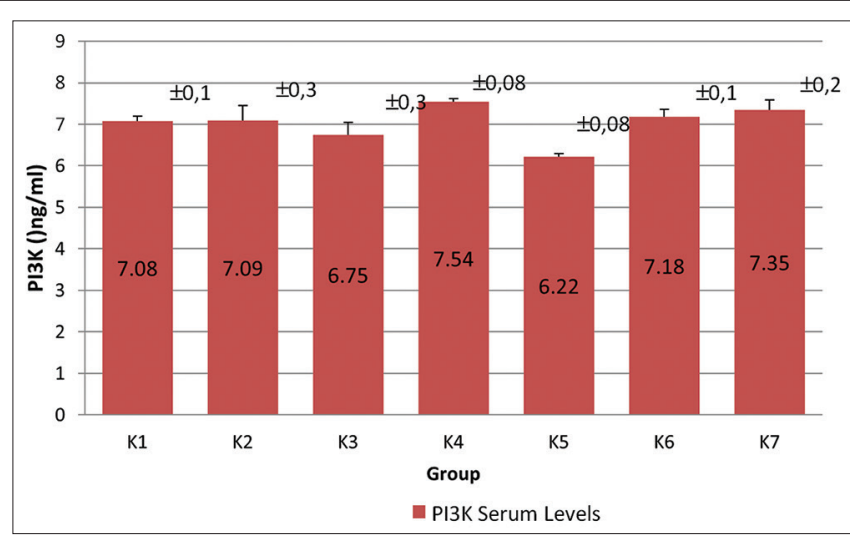

Figure 1: Comparison of mean PI3K serum levels and expression in muscle membrane before and after intervention in seven groups

serum levels score on metformin (K4) administration. In Figure 1, it can also be seen that the PI3K serum levels in the normal group (not T2DM) who received an ethanol extract dose of $250 \mathrm{mg} / \mathrm{kg}$ (K2) had the highest value of all groups.

\section{Discussion}

The experimental animals used in this study were 35 healthy male Wistar rats (Rattus norvegicus sp.) who had met the inclusion and exclusion criteria. Wistar rats were divided into 2 large groups, namely the normal group that was not made the T2DM model $(n=10)$ and the T2DM model group $(n=25)$. All experimental animals in the T2DM model group were induced with a low dose of STZ $30 \mathrm{mg} / \mathrm{kg}$ (1-week interval) after being given a HFD for 5 weeks to make it a T2DM model. Wistar rats that had become T2DM were divided randomly into 5 groups; namely, the T2DM group without treatment $(n=5)$, the T2DM group with metformin $(n=5)$, the T2DM group with the administration of Coffee Arabica Gayo Leaf extract at a dose of $150 \mathrm{mg} / \mathrm{kg} /$ day $(\mathrm{n}=5)$, the DMT2 group was given the Coffee Arabica Gayo Leaf extract at a dose of $200 \mathrm{mg} / \mathrm{kg} /$ day $(\mathrm{n}=5)$, and the T2DM group was given the Coffee Arabica Gayo Leaf extract at a dose of $250 \mathrm{mg} / \mathrm{kg} / \mathrm{day}(\mathrm{n}=5)$. Likewise, the group of mice that were not made the T2DM model was divided into 2 groups randomly, namely the normal control group without treatment $(n=5)$ and the normal control group with the administration of Coffee Arabica Gayo Leaf extract at a dose of $250 \mathrm{mg} / \mathrm{kg} /$ day $(\mathrm{n}=5)$. Hence, the total number of groups $(\mathrm{t})$ in this study was 7 groups consisting of 2 normal groups and 5 T2DM groups. Of these 7 groups, there were 2 groups that did

Table 1: The Mean PI3K serum levels after treatment orally coffee arabica gayo leaf extract in the control and the treatment groups within 30 day

\begin{tabular}{|c|c|c|c|c|c|c|c|c|}
\hline Groups & $\mathrm{K} 1(\mathrm{n}=5)$ & K2 (n=5) & K3 $(n=5)$ & K4 $(n=5)$ & $\mathrm{K} 5(\mathrm{n}=5)$ & K6 $(n=5)$ & K7 $(n=5)$ & $p$ \\
\hline PI3K serum levels $(\mathrm{ng} / \mathrm{mL})$ & $7.08 \pm 0.12$ & $7.09 \pm 0.36$ & $6.75 \pm 0.30$ & $7.54 \pm 0.08$ & $6.22 \pm 0.08$ & $7.18 \pm 0.18$ & $7.35 \pm 0.24$ & $0.037^{*}$ \\
\hline
\end{tabular}


not receive treatment $(\mathrm{K} 1$ and $\mathrm{K} 3)$ and 5 groups that received treatment $(\mathrm{K} 2, \mathrm{~K} 4, \mathrm{~K} 5, \mathrm{~K} 6, \mathrm{~K} 7)$.

Insulin resistance generally involves glucose metabolism in the PI3K pathway. Insulin simultaneously activates the PI3K pathways. Tannin, Saponins, and mostly CGA in extract coffee leaves have been observed to increase glucose uptake by mediators of insulin signaling pathways, such as PI3K. CGA, which is a polyphenol with large amounts in coffee, known to be able to activate glucose utilization through PI3K activation [11], [12]. The antidiabetic effect of flavonoids is mainly due to their modulation effect on blood sugar transporters by increasing insulin secretion, reducing apoptosis, increasing pancreatic $\beta$ cell proliferation, reducing insulin resistance, inflammation and oxidative stress, and increasing GLUT-4 translocation through the PI3K pathway [13], [14].

Intervention of CGA over a long period of time was able to increase PI3K serum levels. In this study, the group which given the Coffee Arabica Gayo Leaf extract at a dose of $150 \mathrm{mg} / \mathrm{kg} / \mathrm{day}, 200 \mathrm{mg} / \mathrm{kg} /$ day and $250 \mathrm{mg} / \mathrm{kg} /$ day have $\mathrm{p}=0.037$. One-way ANOVA test value that shows a $p<0.05$ so that it can be concluded there are effect ethanol extract of Coffee Arabica Gayo Leaf in increased PI3K serum levels.

\section{Conclusion}

In this study, it was found the ethanol extract of Coffee Arabica Gayo Leaf Extract (C. arabica L.) can increase PI3K serum levels greater than the normal group without T2DM and the T2DM group without treatment but not greater than the T2DM group that received metformin in Wistar rats. These data suggest that Coffee Arabica Gayo Leaf Extract can improve $\mathrm{PI} 3 \mathrm{~K}$ serum levels in a rat model type 2 diabetic.

\section{Acknowledgment}

The author gratefully acknowledges that this study is supported by the Universitas Sumatera Utara, the Ministry of Research and Technology, and the Higher Education Republic of Indonesia. This is supported by the grant research DRPM 2020 contract number 11/AMD/ E1/KP.PTNBH/2020 date May 11, 2020. We would also like to thank all who contributed to this research.

\section{References}

1. International Diabetes Federation. IDF Diabetes Atlas. $7^{\text {th }}$ ed Belgium: International Diabetes Federation; 2019.

2. Perkumpulan Endokrinologi Indonesia. Konsensus Pengelolaan dan Pencegahan Diabetes Mellitus Tipe 2 di Indonesia, PB PERKENI; 2015.

3. Martina SJ, Govindan PA, Wahyuni AS. The difference in effect of Arabica coffee Gayo beans and leaf (Coffea arabica Gayo) extract on decreasing blood sugar levels in healthy mice. Open Access Maced J Med Sci. 2019;7(20):3363-5. https://doi. org/10.3889/oamjms.2019.423

4. Ristiana, D. Antioxidant activity and phenol content of various coffee leaf extracts (Coffea Sp.): Potential application of natural ingredients for food fortification. J Aplikasi Teknol Pangan. 2016;6(2):89-92. https://doi.org/10.17728/jatp.205

5. HerlingAW, Schwab D, Burger HJ, Maas J, HammerlR, Schmidt D, et al. Prolonged blood glucose reduction in mrp-2 deficient rats (GY/TR-) by the glucose-6-phosphate translocase inhibitor S 3025. Biochim Biophys Acta Gen Subj. 2002;1569(1-3):105-10. https://doi.org/10.1016/s0304-4165(01)00239-2

6. Marques V, Farah A. Chlorogenic acids and related compounds in medicinal plants and infusions. Food Chem. 2009;113(4):1370-6. https://doi.org/10.1016/j.foodchem.2008.08.086

7. Rodríguez-Gómez R, Vanheuverzwjin J, Souard F, Delporte C Stevigny $\mathrm{C}$, Stoffelen $\mathrm{P}$, et al. Determination of three main chlorogenic acids in water extracts of coffee leaves by liquid chromatography coupled to an electrochemical detector. Antioxidants. 2018;7(10):143. https://doi.org/10.3390/ antiox7100143

8. Farhaty N, Muchtaridi M. Farmaka. J Unpad. 2016;14:214-27. Available from: http://www.jurnal.unpad.ac.id/farmaka. [Last accessed on 2020 Nov 12].

9. Federer WT. Experimental Design: Theory and Application. Pada: Hanafiah KA; 2010. Hanafiah KA. Rancangan PercobaanTeori dan Aplikasi. $3^{\text {rd }}$ ed. Jakarta: Raja Grafindo Persada. 1995. p. 9-10.

10. Vinayagam, $\mathrm{R}, \mathrm{Xu}$ B. Antidiabetic properties of dietary flavonoids: A cellular mechanism review. BMC. 2015;12:60.

11. Jasmine R, Ganesh K, Rajaram R. Probing the mechanism of the antidiabetic potential of a terpenoid from Elephantopus scaber L., an Indian ethnomedicinal plant in STZ diabetic rats-in vivo and in silico analysis. Indian J Biochem Biophys. 2018;55:384-8.

12. Huang X, Liu G, Guo J, Su Z. The PI3K/AKT pathway in obesity and Type 2 diabetes. Int J Biol Sci. 2018;14(11):1483-96. https:// doi.org/10.7150/ijbs. 27173

PMid:30263000

13. Choi J, Kim KJ, Koh EJ, Lee BY. Gelidium elegans extract ameliorates Type 2 diabetes via regulation of MAPK and PI3K/ Akt signaling. Nutrients. 2018;10(1):51. https://doi.org/10.3390/ nu10010051

PMid:29316644

14. Vergotine Z. Molecular Investigation of Genetic Factors Associated with Insulin Resistance and Obesity in a South African Population. South Africa: Stellenbosch University; 2015. Available from: https://www.scholar.sun.ac.za. [Last accessed on 2020 Nov 12]. 